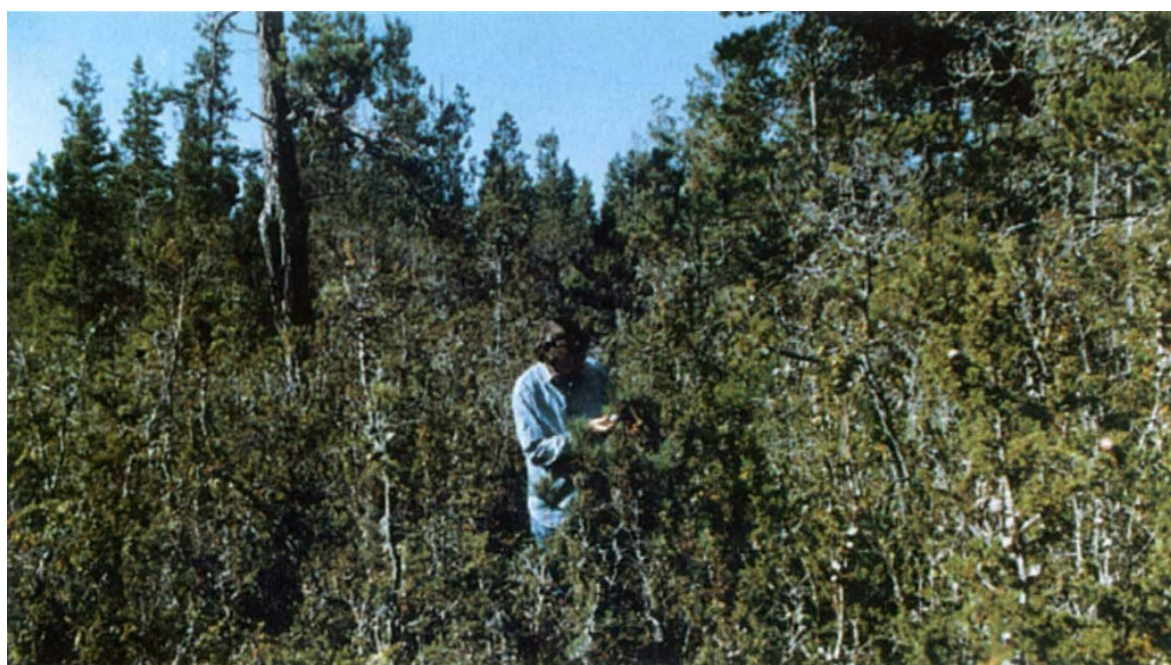

Vegetation in the pygmy forest community studied by Northup et al. ${ }^{2}$. The small but old trees in the foreground exist on highly acidic and infertile soil, and contrast with the much larger specimens of the same species and age rooted in more fertile soil only a short way away. The authors suggest that the stunted community's survival is linked to their greater production of polyphenols, which enables them to use greater amounts of dissolved organic nitrogen as a nutrient source.

teins in soil organic matter, absorbing and transferring the resulting amino acids to their host plants without nitrogen being mineralized to inorganic form ${ }^{6}$.

Northup et al. now show that pine trees growing on infertile soils produce litter with high rates of production of DON (relative to inorganic nitrogen), that could then diffuse to mycorrhizal hyphae or plant roots, thus increasing the supply of DON to plants. They suggest that polyphenols such as tannins mediate this enhanced DON mobilization - plants that can use phenol-bound organic nitrogen could enhance the supply of this form of the nutrient, providing them with a competitive edge over plants that preferentially use ammonium or nitrate as a nitrogen source.

The conventional explanation for high tissue concentrations of phenols is that these compounds defend plants against pathogens $^{7}$ and herbivores ${ }^{8}$. Polyphenols are thought to occur in high concentrations in plants growing on infertile soils either because slow growth in these sites allows carbon to accumulate to levels that can support rapid phenol synthesis, or because the high cost of replacing nutrients lost to herbivores and pathogens in infertile ecosystems selects for high concentrations of phenols as plant defences. However, the plant-defence explanations for patterns of phenol concentrations among plant species have been questioned on two grounds - many herbivores are sensitive only to specific phenolic compounds ${ }^{9}$, and it is often difficult to demonstrate that production of plant defences constitutes a high cost in terms of reduced plant growth ${ }^{10}$.

Convincing tests of Northup and colleagues' hypothesis will require examination of at least two assumptions. The first is that the individual plant that produces these compounds acquires more DON than competing plants, and that the benefit of increased DON absorption exceeds the cost of polyphenol production. It still remains to be shown that Pinus muricata is capable of absorbing organic nitrogen. The second assumption is that selection for phenols to enhance DON acquisition is independent of other factors, such as herbivory, that might have selected for high phenol contents in species or populations occurring on infertile soils. A plausible alternative to the hypothesis of Northup et al. is that plants have adapted to use organic nitrogen in an environment where other factors have selected for high phenol content and resulting release of phenol-protein complexes.

Even as it stands, however, Northup and colleagues' paper makes a substantial contribution to ecology. It offers a hitherto unregarded mechanism by which plants can short-circuit the mineralization step in the nitrogen cycle, and it suggests a novel explanation for patterns of plant secondary chemistry in natural environments.

F. Stuart Chapin III is in the Department of Integrative Biology, University of California, Berkeley, California 94720, USA.

\footnotetext{
Northup, R. R., Yu, Z., Dahlgren, R. A. \& Vogt, K. A. Nature 377, 227-229 (1995).

2. Evans, L. T. Am. Scient. 68, 388-397 (1980).

3. Vitousek, P. M. \& Howarth, R. W. Biogeochemistry 13, 87-115 (1991).

4. Kielland, K. Ecology 75, 2373-2383 (1994).

5. Chapin III, F. S., Moilanen, L. \& Kielland, K. Nature 361. 150-153 (1993).

6. Read, D. J. Experientia 47, 376-391 (1991).

7. Ayres, P. G. in Response of Plants to Multiple Stresses (eds Mooney, H. A.. Winner, W. E. \& Pell, E. J.) 227-248 (Academic, San Diego, 1991).

8. Coley, P. D., Bryant, J. P. \& Chapin III, F. S. Science 230 895-899 (1985).

9. Appel, H. M. J. chem. Ecol. 19, 1521-1552 (1993)

10. Gulmon, S. L. \& Mooney, H. A. in On the Economy of Plant Form and Function (ed. Givnish, T. J.) 681-698 (Cambridge Univ. Press, 1986).
}

\section{Slick thinking}

TANKER owners heroically claim that many oceanic oil slicks are not their fault at all, but are 'natural seepage' from submerged oil-bearing strata. They may have a point. Daedalus now proposes a new source of natural oil slicks.

His reasoning starts from the exhaust catalysts on modern cars, which convert hydrocarbons and oxygen into carbon dioxide and water. Some of them can work this trick quite fast, even at modest temperatures. Now a catalyst is always reversible; it speeds up a reaction just as much backwards as forwards. So, says Daedalus, under the right conditions an exhaust catalyst could take carbon dioxide and water, and turn them back into hydrocarbon and oxygen. Such an 'uphill' reaction would soon grind to a halt unless the hydrocarbon were removed as fast as it formed. One way to do this would be to run the reaction under water. The hydrocarbon, immiscible with water, would continuously rise away from the catalyst surface and float to the top, leaving the catalyst free to make more. The carbon dioxide needed could simply be dissolved in the water. The reaction, essentially combustion in reverse, would absorb heat strongly, and would probably go very slowly. DREADCO's chemists are now trying it, by submerging chunks of various exhaust catalysts in tanks of soda water. A slick of crude oil should slowly form on the water surface - a triumph of theory, perhaps, but hardly the answer to an oil-driller's prayers.

Daedalus, however, claims that nature has got there first. He points out the mysterious shortfall in the atmospheric carbon budget. Despite the millions of tons of carbonaceous fuel and thousands of square miles of tropical forest we are burning every year, the air and the ocean are not accumulating carbon dioxide as they should. Where is it going?

Somewhere in the oceans, says Daedalus, a natural catalyst must be turning it back to oil, and launching it as oil slicks.

Whatever it is, the catalyst must be widely distributed. It may be a freshly precipitated mineral from the superheated 'black smoker' mid-ocean springs. It may be the shell of some ingenious mollusc, designed to mop up excessive carbon dioxide and save itself from dissolution to bicarbonate.

DREADCO oceanographers are now scouring mineral collections and aquaria in search of it. The idea is not to augment the world's oil supply - at least not yet. They want to replace the vastly expensive precious-metal catalysts of car exhausts by a cheap, natural, organic product.

David Jones 